\title{
Papillary Carcinoma of the Thyroid
}

\section{Hepatocyte Growth Factor (HGF) Stimulates Tumor Cells to Release Chemokines Active in Recruiting Dendritic Cells}

\author{
Stefania Scarpino, * Antonella Stoppacciaro, * \\ Francesca Ballerini, * Maurizio Marchesi, ${ }^{\dagger}$ \\ Maria Prat, ${ }^{\ddagger}$ M. Cristina Stella, ${ }^{\S}$ Silvano Sozzani, " \\ Paola Allavena, "I Alberto Mantovani," and \\ Luigi P. Ruco* \\ From the Dipartimento di Medicina Sperimentale e Patologia," \\ and Istituto di III Clinica Chirurgica, ${ }^{\dagger}$ Cattedra di Chirurgia \\ Generale (Prof. Francesco P. Campana), Università "La \\ Sapienza", Roma; the Dipartimento di Scienze Mediche, \\ Università del Piemonte Orientale "A. Avogadro", Novara; the \\ Istituto per la Ricerca sul Cancro (IRCC), ${ }^{\S}$ Università di Torino, \\ Torino; and the Istituto di Ricerche Farmacologiche Mario \\ Negri, ${ }^{\text {"ा }}$ Milano, Italy
}

Tissue distribution of dendritic cells was investigated in eight cases of papillary carcinoma of the thyroid using immunohistochemistry. Most dendritic cells had an immature phenotype $(\mathrm{CD1a}++, \mathrm{CD11c}+$, CD40+, CD86-, HLA-DR-) and were located at the invasion edge of the tumor. This pattern of distribution was profoundly different from that of $\mathrm{CD} 68+$ macrophages, which were evenly distributed throughout the tumor. The ability of tumor cells to release chemotactic factors active on dendritic cells was investigated in primary cultures of the same cases of papillary carcinoma, and was compared to that of the corresponding normal thyroid cells obtained from the tumor-free contralateral lobe. Chemotactic activity of culture supernatants was tested against dendritic cells in a chemotaxis chamber. It was found that papillary carcinoma cells were active in releasing chemotactic activity, that hepatocyte growth factor (HGF; $100 \mathrm{ng} / \mathrm{ml})$ or interleukin (IL)-1 $\beta\left(10^{3} \mathrm{U} / \mathrm{ml}\right)$ induced a fourfold increase in the amount of chemotactic activity released, and that normal thyroid cells obtained from the same patients were as effective as tumor cells. Characterization of chemokines at RNA level revealed that unstimulated cells contain large amounts of IL-8 and monocyte chemotactic protein (MCP)-1 RNAs, and that stimulation with HGF or IL-1 $\beta$ induced RNAs for regulated upon activation normal $T$ expressed and secreted (RANTES), macrophage inflammatory protein (MIP)-3 $\alpha$, interferon- $\gamma$-inducible protein 10 (IP-10), and, to a lesser extent, MIP-1 $\alpha$ and

\begin{abstract}
MIP-1及. The possibility that HGF/Met interaction has a biological role in vivo was investigated in serial sections of six tumors immunostained for $\mathrm{CD1a}+$ Met protein, and HGF. It was found that all six tumors were intensely and diffusely positive for Met protein, that HGF staining was present in tumor cells of the advancing edge, and that $\mathrm{HGF}+/ \mathrm{Met}+$ tumor cell nests were infiltrated by $\mathrm{CD} 1 \mathrm{a}+$ dendritic cells. The foregoing observations are consistent with the possibility that HGF stimulation of Met + tumor cells is one of the molecular mechanisms involved in the recruitment of dendritic cells. (Am J Patbol 2000, 156:831-837)
\end{abstract}

Papillary carcinoma of the thyroid is associated with a striking chronic inflammatory reaction in about 30\% of cases. $^{1,2}$ Inflammatory cells are often aggregated to form an organized lymphoid tissue, defined tumor-associated lymphocytic thyroiditis, which is directed against the tumor and spares the peritumoral normal thyroid. Lymphocytic thyroiditis has a direct influence on tumor prognosis. In two independent studies it has been demonstrated that the presence of lymphocytic thyroiditis is associated with a statistically significant improvement in overall survival and in cancer recurrence rates. ${ }^{3,4}$ Moreover, a significantly greater proportion of patients with lymphocytic thyroiditis belonged to lower pathological tumor-nodemetastasis stages, suggesting that the inflammatory reaction is effective in containing growth and spreading of tumor cells. ${ }^{4,5}$

Experimental studies have demonstrated that dendritic cells have a pivotal role in the development of anti-tumor immunity. ${ }^{6}$ The importance of dendritic cells in papillary thyroid carcinoma is documented by an early study showing that patients with a dense infiltrate of S-100+ dendritic cells in the tumor had a more favorable prognosis irrespective of other morphological and clinical features. ${ }^{7}$ Tissue recruitment of dendritic cells is mediated by chemokines. ${ }^{8}$ Presently, more than 40 chemokines

\footnotetext{
Supported by a grant from AIRC and from MURST 40\%. Accepted for publication October 26, 1999.

Address reprint requests to Prof. Luigi P. Ruco, Dipartimento di Medicina Sperimentale e Patologia, Viale Regina Elena 324, 00161 Roma, Italy. E-mail: ruco@uniroma1.it.
} 
Table 1. Tissue Distribution of S-100+ Dendritic Cells and CD68+ Macrophages in Tumor Sections of Papillary Carcinoma and Medullary Carcinoma of the Thyroid and in Surrounding Normal Thyroid Tissue

\begin{tabular}{|c|c|c|c|c|c|c|c|}
\hline \multirow[b]{2}{*}{ Case no. } & \multirow[b]{2}{*}{ Age/Sex } & \multicolumn{3}{|c|}{ S-100+ dendritic cells } & \multicolumn{3}{|c|}{ CD68+ macrophages } \\
\hline & & $\begin{array}{l}\text { Tumor } \\
\text { periphery }\end{array}$ & $\begin{array}{l}\text { Tumor } \\
\text { inside }\end{array}$ & $\begin{array}{l}\text { Normal } \\
\text { thyroid }\end{array}$ & $\begin{array}{l}\text { Tumor } \\
\text { periphery }\end{array}$ & $\begin{array}{l}\text { Tumor } \\
\text { inside }\end{array}$ & $\begin{array}{l}\text { Normal } \\
\text { thyroid }\end{array}$ \\
\hline \multicolumn{8}{|c|}{ Papillary carcinoma } \\
\hline 1 & $26 / F$ & $0(-)^{*}$ & $1(-)$ & $0(-)$ & 18 & 32 & 4 \\
\hline 2 & $27 / F$ & $49(+1-)$ & $17(-)$ & $0(-)$ & 25 & 17 & 6 \\
\hline 3 & $40 / F$ & $38(+)$ & $9(-)$ & $0(+1-)$ & 47 & 59 & 2 \\
\hline 4 & $18 / F$ & $9(-)$ & $3(-)$ & $\mathrm{np}$ & 49 & 58 & $\mathrm{np}$ \\
\hline 5 & $24 / F$ & $6(-)$ & $1(-)$ & $0(-)$ & 39 & 44 & 5 \\
\hline 6 & $42 / F$ & $35(+1-)$ & $3(-)$ & $0(-)$ & 69 & 82 & 1 \\
\hline 7 & $51 / \mathrm{M}$ & $63(++)$ & $2(+)$ & $2(-)$ & 80 & 42 & 12 \\
\hline 8 & $32 / F$ & $11(+)$ & $8(+1-)$ & $\mathrm{np}$ & 92 & 88 & $\mathrm{np}$ \\
\hline \multicolumn{8}{|c|}{ Medullary carcinoma } \\
\hline 20 & $63 / F$ & $0(-)$ & $0(-)$ & $0(-)$ & 14 & 13 & 1 \\
\hline 21 & $35 / \mathrm{M}$ & $0(-)$ & $0(-)$ & $0(-)$ & 13 & 16 & 0 \\
\hline 22 & $51 / \mathrm{M}$ & $0(-)$ & $0(-)$ & $0(-)$ & 18 & 15 & 2 \\
\hline
\end{tabular}

Paraffin sections of the tumor were immunostained for S-100 protein and for CD68 using ABC-peroxidase. The number of immunostained cells present in a $250 \times$ microscope field are reported. Positive cells were counted at the periphery of the tumor, ie, the advancing edge, inside the tumor and in peritumoral normal thyroid tissue.

*Symbol in parentheses indicates presence and extent of the lymphocytic infiltrate in each site; -, absent; +/-, mild; +, moderate; ++, rich; np, not present.

have been identified that bind to about 10 generally promiscuous chemokine receptors expressed by leukocytes. ${ }^{9,10}$ In the present study we have investigated the molecular mechanisms involved in dendritic cell recruitment in papillary carcinoma of the thyroid.

\section{Materials and Methods}

\section{Cell Cultures}

Primary cultures of normal and neoplastic thyroid cells were established from surgically removed thyroids. None of the patients had a previous history of hypothyroidism or of Hashimoto thyroiditis; moreover, a histological picture consistent with Hashimoto thyroiditis was not observed in thyroid sections. All of the patients were evaluated for autoantibodies and were negative. In brief, fragments of 12 papillary carcinomas, 1 medullary carcinoma, and normal-appearing thyroid tissue obtained from the tumor-free contralateral lobe or from the peritumoral histologically normal tissue of the same patients, were digested with a collagenase-hyaluronidase mixture (Sigma, Milan, Italy) for 2 hours at $37^{\circ} \mathrm{C}$. Cells were washed $3 \times$ with phosphate buffered saline, and were plated on Primaria plates (Falcon, NJ) at a density of $1 \times$ $10^{6}$ cells/75 ml flask. ${ }^{11,12}$ Primary cultures were maintained in Dulbecco's modified Eagle's medium (DMEM, GIBCO, Scotland) supplemented with 10\% fetal bovine serum (passaged FBS; Life Technologies, Milan, Italy), and were passed every 15 days for a period of 60 days.

Normal and tumor cells grew as adherent cells, formed a confluent monolayer after 10 to 20 days, had epithelial morphology, and were immunostained for cytokeratin and thyroglobulin (Dako, Dakopatts, Glostrup, Denmark). Cultured thyroid cells were responsive to thyroid-stimulating hormone (TSH; Sigma); in fact, exposure for 48 hours to $200 \mathrm{ng} / \mathrm{ml}$ induced a two- to threefold increase in the percentage of thyroglobulin-positive cells. The per- centage of thyroglobulin-positive cells decreased with time, and was extremely low after 60 days of culture.
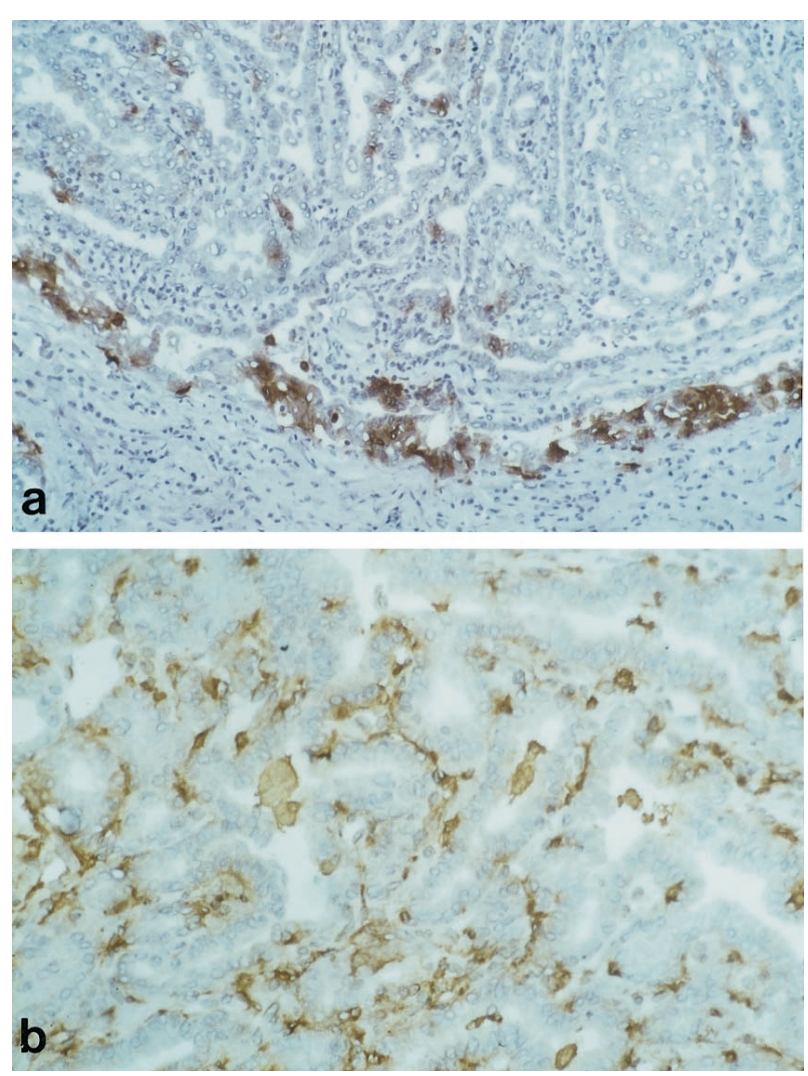

Figure 1. Cryostat sections of a case of papillary carcinoma of the thyroid immunostained for CD1a (a) and for CD68 (b). Tumor-associated CD1a+ dendritic cells and CD68+ macrophages show a different pattern of distribution. Most CD1a+ dendritic cells are located in correspondence of the advancing edge of the tumor. CD68+ macrophages are present throughout the tumor, in the connective stroma of the papillae and in the follicle lumen. Original magnifications, $\times 250$ (a) and $\times 400(\mathbf{b})$; ABC-peroxidase, counterstained with hematoxylin. 
Table 2. Chemotactic Activity for Dendritic Cells present in 72 -Hour Supernatants of Primary Cultures of Tumor Cells and of Normal Thyroid Cells Obtained from the Same Patients

\begin{tabular}{|c|c|c|c|c|c|c|c|}
\hline \multirow[b]{2}{*}{ Case no. } & \multirow[b]{2}{*}{ Histology } & \multicolumn{3}{|c|}{ Tumor cell supernatant } & \multicolumn{3}{|c|}{ Normal cell supernatant } \\
\hline & & $1 / 3$ & $1 / 9$ & $1 / 27$ & $1 / 3$ & $1 / 9$ & $1 / 27$ \\
\hline 1 & Papillary carcinoma & $18 \pm 3$ & $12 \pm 4$ & 0 & $28 \pm 2$ & $12 \pm 3$ & 0 \\
\hline 2 & Papillary carcinoma & $19 \pm 2$ & $19 \pm 1$ & $9 \pm 2$ & $17 \pm 4$ & $10 \pm 4$ & $7 \pm 3$ \\
\hline 3 & Papillary carcinoma & $33 \pm 5$ & $14 \pm 3$ & $5 \pm 2$ & $14 \pm 4$ & $7 \pm 2$ & $4 \pm 2$ \\
\hline 4 & Papillary carcinoma & $25 \pm 2$ & $18 \pm 1$ & $11 \pm 2$ & $27 \pm 3$ & $19 \pm 2$ & $6 \pm 2$ \\
\hline 5 & Papillary carcinoma & $15 \pm 1$ & $23 \pm 2$ & $13 \pm 2$ & $12 \pm 4$ & $33 \pm 2$ & $24 \pm 5$ \\
\hline 6 & Papillary carcinoma & $15 \pm 4$ & $14 \pm 2$ & $5 \pm 1$ & $9 \pm 2$ & $2 \pm 1$ & 0 \\
\hline 7 & Papillary carcinoma & $23 \pm 3$ & $10 \pm 2$ & 0 & na & na & na \\
\hline 7 & $\begin{array}{l}\text { Lymph node metastasis of } \\
\text { papillary carcinoma }\end{array}$ & $10 \pm 2$ & $9 \pm 3$ & $5 \pm 4$ & & & \\
\hline MIP-1 $\alpha(1$ & $\begin{array}{l}\text { Medullary carcinoma } \\
\mathrm{g} / \mathrm{ml})=34 \pm 4 ;{ }^{*} \operatorname{NPAP}(1 / 3)\end{array}$ & $\begin{array}{l}2 \pm 1 \\
\operatorname{MTC}(1 /\end{array}$ & $\begin{array}{r}7 \pm 3 \\
30 \pm 2\end{array}$ & $\begin{array}{r}9 \pm 3 \\
(1 / 3)=\end{array}$ & na & na & na \\
\hline
\end{tabular}

Chemotactic activity for dendritic cells was investigated in 72-hour supernatants obtained from primary cultures of papillary carcinoma cells (seven primary tumors and one lymph node metastasis) and one medullary carcinoma. Release of chemotactic activity by tumor cells was compared with that of the corresponding normal thyroid cells obtained from the tumor-free contralateral lobe. In Cases 3 and 6 the contralateral normal lobe contained small isolated foci of chronic lymphocytic thyroiditis. All the experiments were made with thyroid cells kept in culture for no longer than 45 days. Three dilutions $(1 / 3,1 / 9,1 / 27)$ of each supernatant were tested in 48-well chemotaxis chambers using dendritic cells differentiated in vitro from blood monocytes as target cells. Migrated cells were counted microscopically in five randomly selected fields per well. The assay was performed in triplicate and as positive control of migration, MIP- $1 \alpha$ was used (100 $\mathrm{ng} / \mathrm{ml})$. NLTT.

${ }^{*}$ Chemotactic activity of $1 / 3$ dilution of supernatants obtained from three thyroid cell lines established from normal thyroid tissue. NPAP; MTC na, not available.

Chemotactic activity was evaluated in supernatants of thyroid cells kept in culture for no longer than 45 days in $10 \%$ fetal bovine serum (FBS). In some experiments, thyroid cells were starved for 24 hours, then incubated for additional 6 to 24 hours with one of the following activating agents: 20-100 $\mathrm{ng} / \mathrm{ml}$ HGF (recombinant human HGF, produced in the baculovirus expression system, and activated by overnight incubation with $\mathrm{FBS}^{13}$ ), 200 $\mathrm{ng} / \mathrm{ml} \mathrm{TSH}, 20 \mathrm{ng} / \mathrm{ml}$ epidermal growth factor (EGF), $10^{3}$ $\mathrm{U} / \mathrm{ml}$ interleukin-1 $\beta$ (IL-1 $\beta$ ), Chemicon International, CA), or $10 \%$ FBS, before collection of supernatants.

\section{Migration Assay}

Cell migration was evaluated using a chemotaxis chamber (Neuroprobe, Pleasanton, CA), and polycarbonate filter (5 $\mathrm{mm}$ pore size, Neuroprobe) as previously described. ${ }^{14,15}$ Progressive dilutions of culture supernatants $(1 / 3,1 / 9$, and $1 / 27)$ were used as chemoattractants. Cell suspensions $\left(0.7-1.0 \times 10^{6} / \mathrm{ml}\right)$ were incubated at $37^{\circ} \mathrm{C}$ for 90 minutes. Results are expressed as the mean number of migrated cells in five high power fields $(1000 \times)$. Each experiment was performed in triplicate.

Dendritic cells were differentiated in vitro as previously described. ${ }^{14,15}$ Blood monocytes (>95\% CD14+), obtained by Ficoll and Percoll gradients, were purified by panning on CD6-coated plastic dishes. Monocytes were cultured for 7 days at $1 \times 10^{6} / \mathrm{ml}$ in RPMl 1640 (Biochrom, Germany), 10\% FCS (Hyclone, Logan, UT), with $50 \mathrm{ng} / \mathrm{ml}$ GM-CSF and $10 \mathrm{ng} / \mathrm{ml} \mathrm{IL-13.} \mathrm{IL-13} \mathrm{was} \mathrm{a} \mathrm{gift}$ from Dr. A. Minty (Sanofi Elf Bioa Recherces, Labège, France). MIP- $1 \alpha$ was from Pepro Tech, Inc. (Rocky Hill, NJ). GM-CSF was obtained from Novartis, Italy.

\section{RNase Protection Assay (RPA) and Reverse Transcription-Polymerase Chain Reaction}

Total RNA was extracted from unstimulated cells, HGFstimulated $(20-100 \mathrm{ng} / \mathrm{ml}$ for 10 minutes or 6,24 , or 72 hours) cells using RNA FAST (Molecular System, San Diego, CA).

In RPA, multiprobe template sets hCK-5 (containing DNA template for lymphotactin (Ltn), RANTES, IP-10, MIP- $1 \beta$, MIP- $1 \alpha$, monocyte chemotactic protein-1 (MCP1), IL-8, I-309, L32, and GAPDH) were purchased from Pharmingen (Becton Dickinson, San Diego, CA). The DNA template were used to synthesize the $\left[\alpha^{32} \mathrm{P}\right]$ UTP (3000 Ci/mmol, $10 \mathrm{mCi} / \mathrm{ml}$, Amersham Life Science, Little Chalfont, UK) labeled probes in the presence of a GACU pool (GTP + ATP + CTP + VTP) using a T7 RNA polymerase (Promega, Madison, WI). Hybridization with 5 to $10 \mu \mathrm{g}$ of each target RNA was performed overnight followed by digestion with RNase A and T1. The samples were treated by proteinase $\mathrm{K} /$ sodium dodecyl sulfate mixture and then extracted with chloropan and precipitated in the presence of ammonium acetate. The samples were loaded on an acrylamide-urea sequencing gel next to the labeled probes, and run at $36 \mathrm{~W}$ with $0.5 \%$ Trisborate/EDTA. The gel was absorbed to filter paper, dried under vacuum, and exposed on Kodak X-AR film with intensifying screen at $-70^{\circ} \mathrm{C}$.

Single-strand cDNA was synthesized from $2 \mu \mathrm{g}$ total RNA using avian myeloblastosis virus-reverse transcriptase (Promega). Primers used for polymerase chain reaction (PCR) were: MIP-3 $\beta$ (Epstein-Barr virus-induced molecule 1 ligand chemokine): 5'-GTC ATA GGT TAA CTG CTG CGG CG-3' and 5'-TGG CAC CAA TGA TGC TGA AGA CTG-3', amplifying a 243-bp product; MIP-3 $\alpha$ (liver- and activation-regulated chemokine): 5'-TTA CAT 
2a

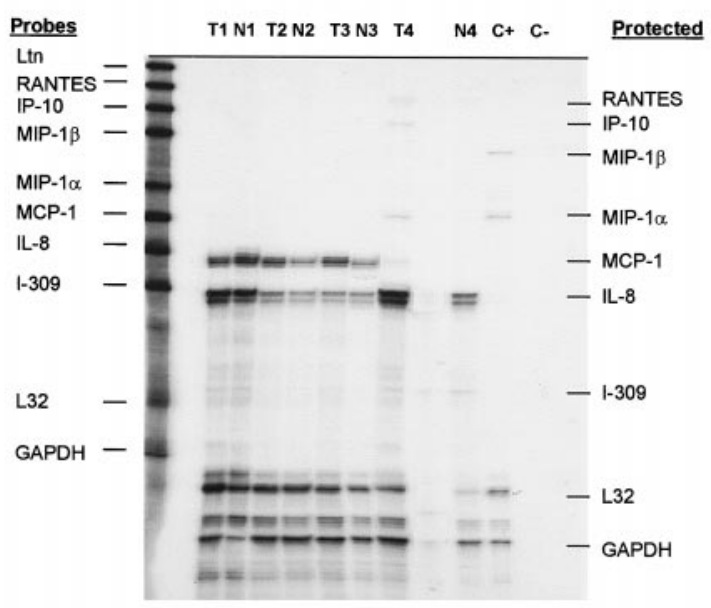

2b

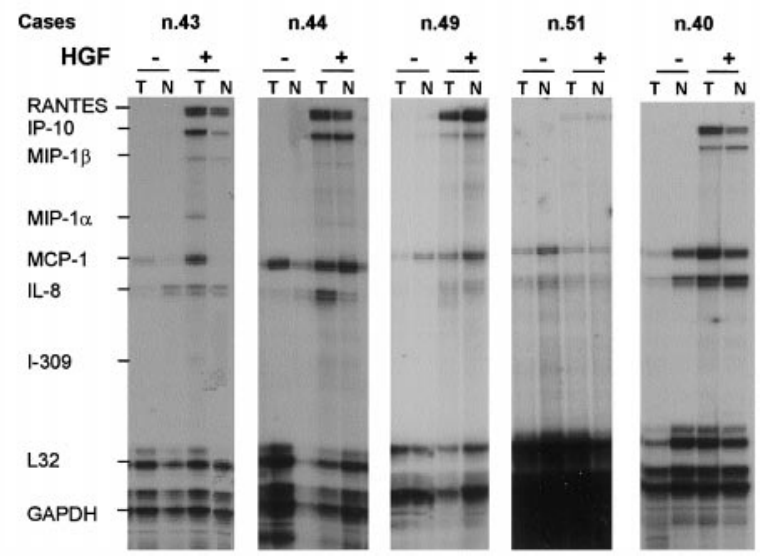

Figure 2. a: Total RNA extracted from primary cultures of papillary carcinoma cells $(\mathrm{T})$ or of normal thyroid cells $(\mathrm{N})$ were hybridized with multi probe template set kit from Pharmingen labeled with ${ }^{32} \mathrm{P} \alpha$-UTP. After single strand RNA digestion the samples were run on a sequencing gel, dried, and exposed on Kodak X-AR film for 24 hours. b: Primary cultures of 5 cases of papillary carcinoma cells $(\mathrm{T})$ and of the corresponding normal thyroid cells (N) were cultured for 24 hours with or without $100 \mathrm{ng} / \mathrm{ml} \mathrm{HGF}$. Total RNA was extracted and was hybridized with multi probe template set kit from Pharmingen labeled with ${ }^{32} \mathrm{P} \alpha$-UTP. After single strand RNA digestion the samples were run on a sequencing gel, dried, and exposed on Kodak X-AR film for 24 hours.

GTT CTT GAC TTT TTT ACT GAG GAG-3' and 5'-ATG TGC TGT ACC AAG AGT TTG C-3' amplifying a 292-bp product; $\beta$-actin: 5'-CAG TGA GGA TCT TCA TGA CC-3' and 5'-CTA CAA TGA GTC GCG TGT GG-3' amplifying a 313-bp product. cDNA were amplified by PCR using the following conditions: 35 cycles of 1 minute at $94^{\circ} \mathrm{C}, 1$ minute at $50^{\circ} \mathrm{C}$ or $55^{\circ} \mathrm{C}$ or $59^{\circ} \mathrm{C}$ (depending on the primer pair), and 1 minute at $72^{\circ} \mathrm{C}$. PCR products were resolved on a $1.5 \%$ agarose gel containing ethidium bromide.

\section{Immunohistochemistry}

Dendritic cells and macrophages were visualized in deparaffinized sections of thyroid tumors immunostained for S-100 protein (1:600) and CD68 (1:300; Dakopatts).
Dendritic cell phenotyping was achieved in cryostat sections of fresh tumor tissue. Fragments of fresh tissue were embedded in optimal cryopreserving tissue (OCT) compound (Miles, Elkhart, IN), snap-frozen in liquid nitrogen, and stored at $-80^{\circ} \mathrm{C}$ until sectioning. Acetone-fixed cryostat sections were incubated with anti-CD1a (1:20, Ortho Clinical Diagnostics, Raritan, NJ), CD11c (1:200, Pharmingen International, CA), CD40, (1:200 Cymbus Biotechnology, UK), CD86 (1:200, Pharmingen), HLA-DR (1:25, Dakopatts) for 30 minutes. Met protein (DO-24, 1:200) and HGF (DV-14, 1:200) were demonstrated with mouse monoclonal antibody whose specificity was previously described. ${ }^{16,17}$ Sections were then sequentially incubated with biotinylated anti-mouse immunoglobulins followed by streptavidin-peroxidase complex (DAKO LSAB Kit-peroxidase, Dakopatts). Each incubation step lasted 10 minutes with multiple 5-minute Tris-buffered saline washes between each step. The reaction product was developed using $0.03 \% \mathrm{H}_{2} \mathrm{O}_{2}$ and $0.06 \%$ 3,3'-diaminobenzidine (Dako DAB, Dakopatts) .

\section{Results}

Macrophages and dendritic cells present in papillary carcinoma of the thyroid were characterized by immunohistochemistry in tumor sections. It was found that macrophages and dendritic cells have a different pattern of distribution (Table 1). In fact, most CD1a+/S-100+ dendritic cells were located at the invasion edge of the tumor (Figure 1a), whereas CD68+ macrophages were evenly distributed throughout the tumor (Figure 1b). Tumor-associated dendritic cells had an immature phenotype, being intensely positive for CD1a, moderately positive for CD11C and CD40, and negative for CD86 and HLA-DR. Dendritic cells were extremely rare in the peritumoral normal thyroid tissue and in 3 cases of medullary carcinoma (Table 1). This latter finding raised the possibility that tumor cells of papillary carcinoma were actively involved in recruitment of dendritic cells.

The ability of thyroid cells to release chemotactic factors active on dendritic cells was investigated in primary cultures of papillary carcinoma cells and of normal thyroid cells obtained from the tumor-free contralateral lobe of the same patients (Table 2). Normal and tumor cells grew as adherent cells, had epithelial morphology, were immunostained for thyroglobulin, were responsive to TSH, and maintained a differentiated phenotype for 60 days in culture. Chemotactic activity of culture supernatants was tested against monocyte-derived dendritic cells using a chemotaxis chamber. Culture supernatants of papillary carcinoma cells and normal thyroid cells were all active in inducing dendritic cell migration, with no significant difference between normal cells and tumor cells. Furthermore, in Case 7 we had the opportunity to demonstrate chemotactic activity in tumor cell cultures obtained from the primary tumor and from a metastatic lymph node as well. Chemotactic activity was extremely low in the supernatant of the single case of medullary carcinoma that we had the opportunity to study. RNA was extracted from cultured normal and tumor cells in four 


\section{N. of migrated DC}

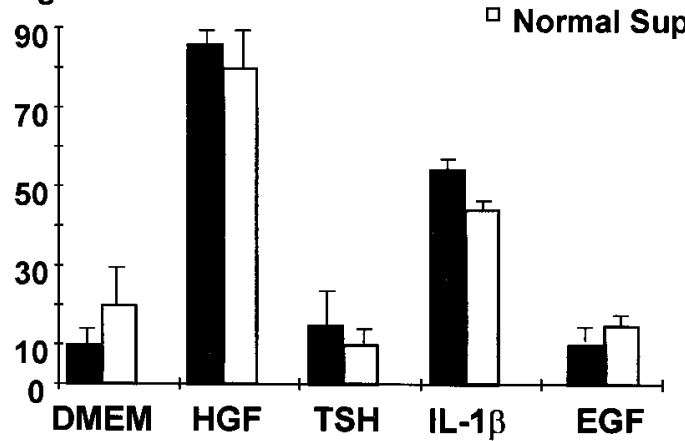

Figure 3. Supernatants were harvested from normal or tumor cells starved for 24 hours and then incubated for additional 24 hours with $100 \mathrm{ng} / \mathrm{ml} \mathrm{HGF}$, $200 \mathrm{ng} / \mathrm{ml} \mathrm{TSH}, 20 \mathrm{ng} / \mathrm{ml} \mathrm{EGF}$, or $10^{3} \mathrm{U} / \mathrm{ml} \mathrm{IL}-1 \beta$. Supernatants were tested for chemotactic activity against monocyte-derived dendritic cells in 48-well chemotaxis chamber. Mean of migrated cells counted in 5 oil microscope fields are reported in the figure. All experiments were performed in triplicate.

cases and was tested for chemokine mRNA transcripts using an RNase protection assay. Among the investigated chemokines, cultured cells contained only IL-8 and MCP-1 mRNAs; only in Case 4 were they also weakly positive for MIP-1 $\alpha$ mRNA (Figure 2a).

It was previously demonstrated that cytokine production by thyroid cells is stimulated by $\mathrm{IL}-1$ and is poorly affected by TSH. ${ }^{18,19}$ In the experiments reported in Figure 3 , the stimulatory capacity of $\mathrm{IL}-1 \beta, \mathrm{TSH}, \mathrm{EGF}$, and HGF was investigated. It was found that HGF and IL-1 $\beta$ were the only factors effective in increasing the release of chemotactic activity by papillary carcinoma cells and by normal cells. TSH and EGF, although ineffective in inducing chemokine release, were nonetheless active in upregulating thyroglobulin synthesis (TSH) and inducing thyroid cell proliferation (EGF; data not shown). Thyroid cell stimulation with $\mathrm{HGF}$ or with $\mathrm{IL}-1 \beta$ resulted in the appearance of RANTES and IP-10 mRNAs, and to a lesser extent of MIP- $1 \alpha$ and MIP- $1 \beta$ in five investigated cases (Figure $2 b$ ). IL-1 $\beta$ was maximally effective after 6 hours, whereas HGF action was more pronounced at 24 hours (Figure 4). In separate experiments we have investigated the ability of HGF to induce MIP-3 $\alpha$ RNA using a reverse transcriptase-polymerase chain reaction, and we have observed a maximal response after 24 hours' incubation with $100 \mathrm{ng} / \mathrm{ml} \mathrm{HGF} \mathrm{(Figure} \mathrm{5).}$

HGF was included in this study because tumor cells of papillary carcinoma of the thyroid are characterized by prominent expression of Met protein, which is the high affinity receptor for HGF. ${ }^{20,21}$ The possibility that HGF/ Met interaction has a role in determining dendritic cell recruitment into tumor was investigated in serial sections of six cases immunostained for CD1a+, Met protein, and HGF. Immunostaining for Met protein was diffusely present in all six tumors and was not observed in normal thyroid tissue as previously reported. ${ }^{20,21}$ HGF staining was present in a small fraction of tumor cells located at the periphery of the tumor or infiltrating the peritumoral normal thyroid. Immunostaining of serial sections allowed us to establish that HGF+/Met+ tumor cell nests were infiltrated by CD1a+ dendritic cells (Figure 6).
$A(6 h)$

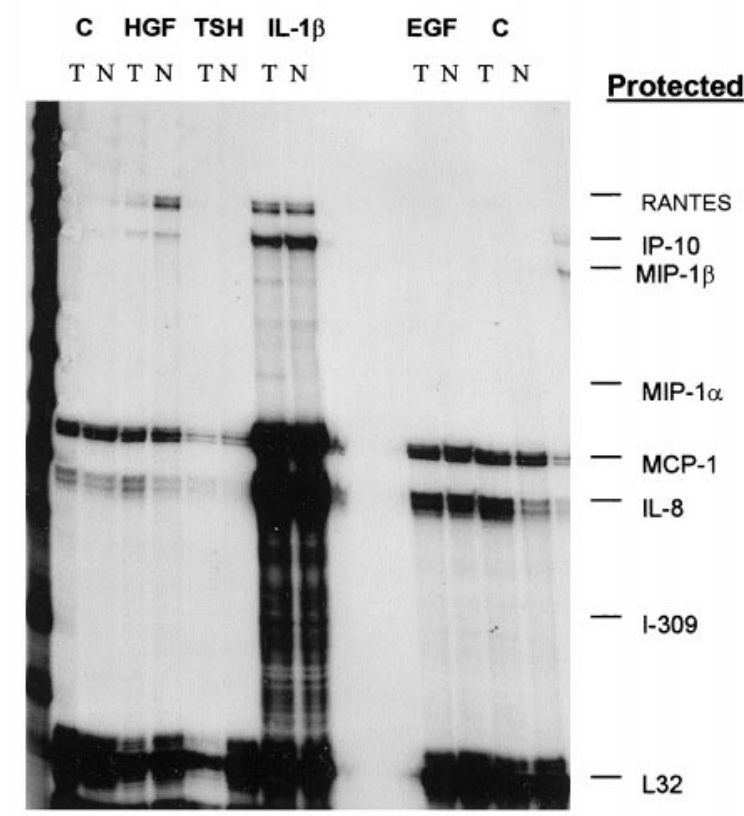

\section{B (24h)}

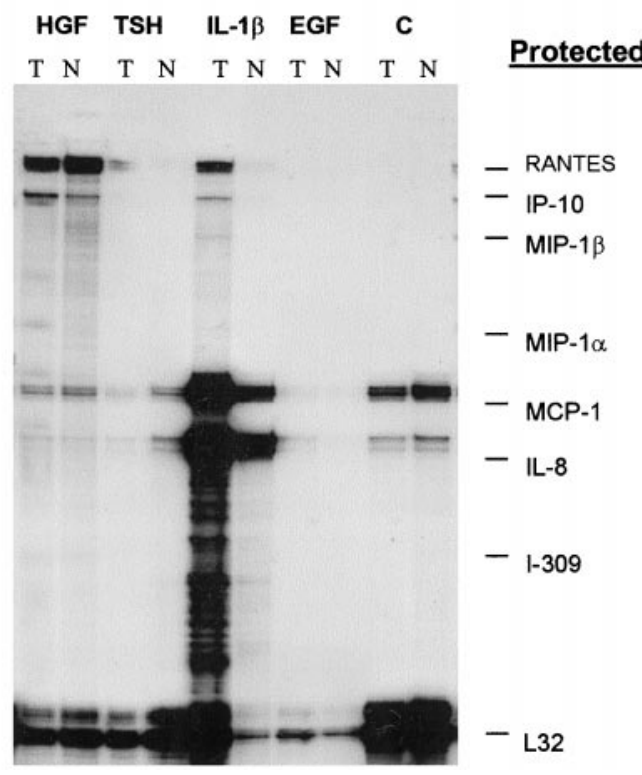

Figure 4. Normal and tumor cells were stimulated $100 \mathrm{ng} / \mathrm{ml}$ HGF, 200 $\mathrm{ng} / \mathrm{ml} \mathrm{TSH}, 20 \mathrm{ng} / \mathrm{ml} \mathrm{EGF}$, or $10^{3} \mathrm{U} / \mathrm{ml} \mathrm{IL}-1 \beta$ for 6 (A) or 24 (B) hours Between 5 and $10 \mu \mathrm{g}$ of total RNA extracted from tumor or normal cells were hybridized with multiprobe template set kit from Pharmingen labeled with ${ }^{32} \mathrm{P} \alpha$-UTP. After single strand RNA digestion the samples were run on a sequencing gel, dried, and exposed on Kodak X-AR film for 24 hours.

\section{Discussion}

Papillary carcinoma of the thyroid is characterized by overexpression of Met protein, the high affinity receptor for HGF, in a large proportion (>95\%) of the cases. ${ }^{20,21}$ It has already been demonstrated that HGF/Met interaction 


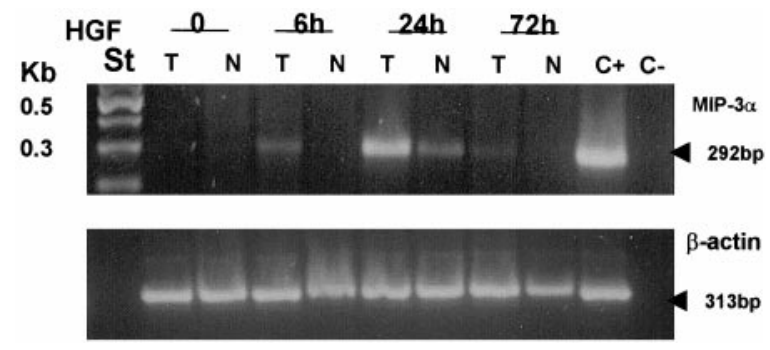

Figure 5. Normal or papillary carcinoma cells were stimulated for 6, 24, or 72 hours with $100 \mathrm{ng} / \mathrm{ml} \mathrm{HGF}$. Single strand cDNA was synthesized from $2 \mu \mathrm{g}$ total RNA using AMV-RT. Primers used for PCR were MIP- $3 \alpha$ (amplifying a 292-bp product) and $\beta$-actin (amplifying a 313-bp product). PCR products were resolved on a $1.5 \%$ agarose gel containing ethidium bromide.

is biologically active in this tumor. In fact, HGF induces a significant increase in tumor cell invasiveness in vitro ${ }^{12}$ and stimulates adhesion of tumor cells to extracellular matrix components (Scarpino S, unpublished observation). In the present study we provide evidence that HGF/ Met interaction contributes to intratumoral recruitment of inflammatory cells through induction of chemokine release by tumor cells. In fact, we have shown that on HGF stimulation, papillary carcinoma cells produce mRNAs for RANTES, IP-10, MIP- $1 \alpha$, MIP- $1 \beta$, and MIP-3 $\alpha$ and release chemotactic activities for dendritic cells. It is reasonable to postulate that HGF-induced chemokine production is one of the possible pathways for development of chronic lymphocytic thyroiditis in papillary carcinoma. In this regard it is of interest that another malignant tumor of thyrocyte origin, the follicular carcinoma, does not overexpress Met protein and is rarely associated with chronic thyroiditis.

HGF action is limited by the availability of HGF in the tumor microenvironment. It has been reported that HGF is constitutively produced by normal fibroblasts ${ }^{22}$ and is present in the connective stroma of the thyroid. ${ }^{23}$ We have investigated the presence of HGF in tumor sections using immunohistochemistry and have demonstrated that HGF production is confined to small clusters of cells located in the advancing edge of the tumor. This peculiar location may be related to the role that HGF/Met interaction has in favoring tumor invasiveness. In addition, it may provide an explanation for recruitment of dendritic cells selectively at the periphery of the tumor. Indeed we have shown that dendritic cells and macrophages were both present within the tumor, but exhibited a different pattern of distribution. Our observations are supportive of the existence of finely regulated mechanisms of chemokine release in tumors which might lead to selective recruitment of definite leukocyte subpopulations in a given site. ${ }^{24}$

Dendritic cells associated with the tumor had an immature phenotype (CD1a+/S-100+/CD86-/HLA-DR-). Immature dendritic cells are particularly active in antigen uptake, but are poorly effective in antigen presentation and $\mathrm{T}$ lymphocyte stimulation. ${ }^{25,26}$ It has been demonstrated that immature dendritic cells are attracted by MIP- $1 \alpha$, MIP- $1 \beta$, RANTES, MCP-2, $-3,-4$, and MIP-3 $\alpha$ released at sites of injury. ${ }^{10,27}$ On maturation, dendritic cells loose reactivity to MIP- $3 \alpha$, through down-regulation of CCR6 receptor, and acquire reactivity to MIP-3 $\beta$ through up-regulation of CCR7. MIP-3 $\beta$ is produced in
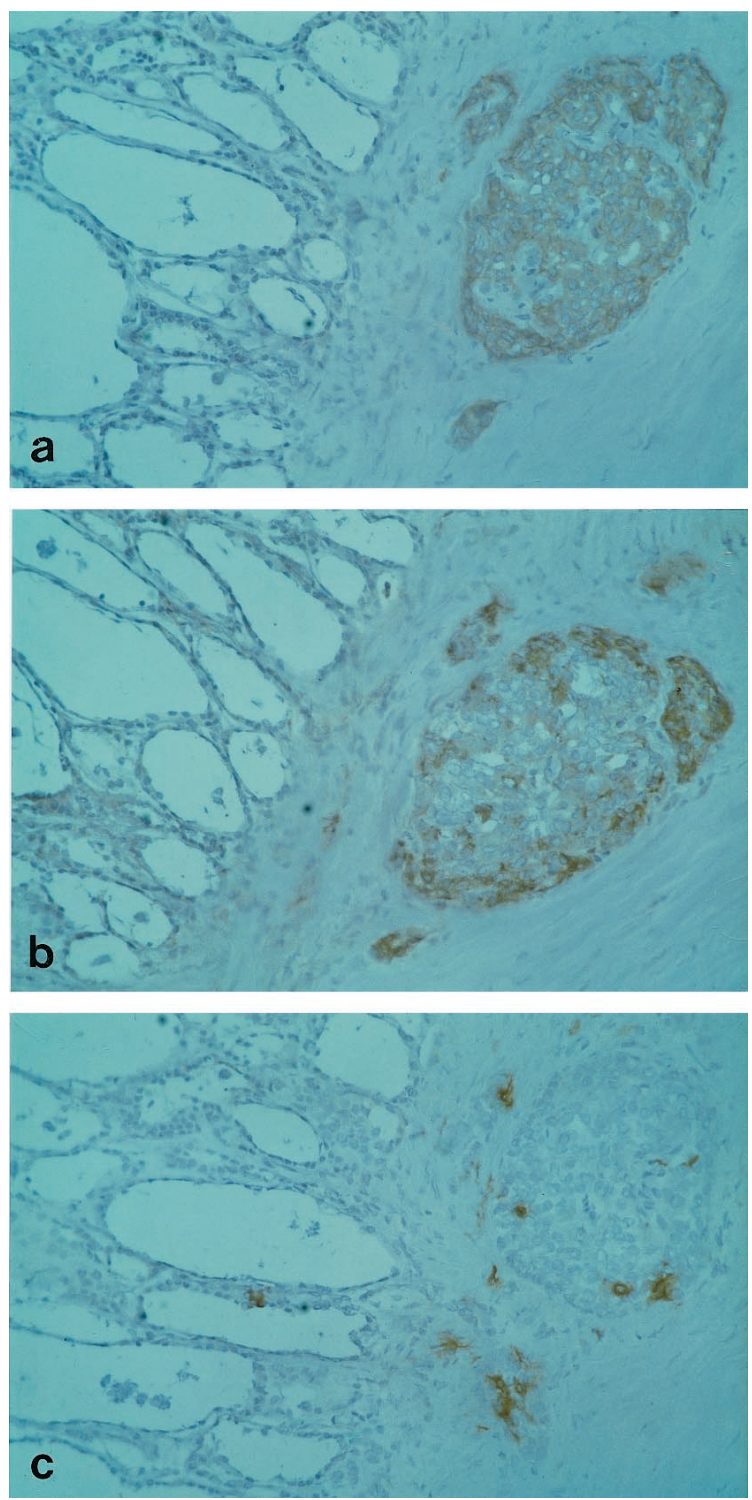

Figure 6. Serial sections of a case of papillary carcinoma of the thyroid immunostained for (a) Met protein (DO-24), (b) HGF (DV-14), or (c) dendritic cells (CD1a). The pictures show a large tumor cell nest adjacent to a rim of normal thyroid. Most tumor cells are immunostained for Met protein, whereas reactivity for HGF is prominent only in the outer cells facing the connective stroma. Numerous CD1a + dendritic cells infiltrate the tumor area. The normal thyroid tissue is negative for Met protein and for HGF, and contains a single CD1a+ dendritic cell. Original magnifications, $\times 250$; ABCperoxidase, counterstained with hematoxylin.

lymphoid tissues where antigen-pulsed dendritic cells are then attracted, and become effective in stimulating $T$ lymphocytes. The results of our immunohistochemical study are consistent with this model. Furthermore, the existence of an intense traffic of dendritic cells through papillary carcinoma is proven by several descriptions of prominent accumulation of dendritic cells in draining lymph nodes. In some of these cases, the accumulation of dendritic cells was so pronounced that a diagnosis of Langerhans cell histiocytosis was taken in consideration. ${ }^{28-31}$

This is the first report describing that HGF induces synthesis and release of chemokines in epithelial cells, and more specifically in thyroid cells. It is of interest that 
HGF activity was not exerted by other growth factors (TSH, EGF, or $10 \% \mathrm{FBS}$ ) active on thyrocytes, raising the possibility of a selective mechanism of thyroid cell regulation. Our findings extend those of previous studies showing that cultured thyroid cells produce IL-8 and MCP-1, and can be stimulated by IL-1 to increase chemokine production. ${ }^{18,19}$ Surprisingly, we have found that normal thyroid cells and tumor cells were equally effective in releasing chemotactic activity for dendritic cells in culture supernatants. This finding is in open conflict with the observation that dendritic cells are extremely rare in normal thyroid tissue, and raises the possibility that culture conditions act as a stimulatory signal for normal thyroid cells. In support of this view, we have already reported that normal thyroid cells of primary cultures express high levels of Met protein and of urokinasetype plasminogen activator receptor (uPA-R), ${ }^{12}$ whereas normal thyroid cells of tissue sections do not. ${ }^{20,21}$ The biological role of Met protein in normal thyrocytes is still undefined. We have observed that moderate expression of Met protein is present in fetal thyroid, in Hürthle cells of Hashimoto thyroiditis, and in hyperfunctioning thyrocytes of Graves' disease. ${ }^{20,21}$ Taken together, our findings may indicate that up-regulation of Met receptor is an early event in thyroid cell alteration induced by various agents. In some of these instances, stimulation of Met receptor by environmental HGF might cause chemokine release, pericellular accumulation of inflammatory cells, and elimination of damaged thyroid cells. If this is true, HGF/Met interaction might represent one of the molecular mechanisms aimed at the maintenance of the integrity of the thyroid gland.

\section{Acknowledgments}

We thank Ms. Anna Pasquini for her skillful technical assistance with the immunohistochemical stainings, Dr. Giovanna D'Amico for dendritic cell cultures, and Mr. Walter Luini for the chemotaxis experiments.

\section{References}

1. Carcangiu ML, Zampi G, Pupi A, Castagnoli A, Rosai J: Papillary carcinoma of the thyroid: a clinicopathologic study of 241 cases treated at the University of Florence, Italy. Cancer 1985, 55:805-828

2. Rosai J, Carcangiu ML, De Lellis LA: Tumors of the thyroid gland. Atlas of Tumor Pathology. Washington, DC, Armed Forces Institute of Pathology, 1992

3. Kashima K, Yokoyama S, Noguchi S, Murakami N, Yamashita H, Watanabe S, Uchino S, Toda M, Sasaki A, Daa T, Nakayama I: Chronic thyroiditis as a favorable prognostic factor in papillary thyroid carcinoma. Thyroid 1998, 8:197-202

4. Loh KC, Greenspan FS, Dong F, Miller TR, Yeo PP: Influence of lymphocytic thyroiditis on the prognostic outcome of patients with papillary thyroid carcinoma. J Clin Endocrinol Metab 1999, 84:458-463

5. Schaffler A, Palitzsch KD, Seiffarth C, Hohne HM, Riedhammer FJ, Hofstadter F, Scholmerich J, Ruschoff J: Coexistent thyroiditis is associated with lower tumour stage in thyroid carcinoma. Eur $\mathrm{J}$ Clin Invest 1998, 28:838-844

6. Pardoll DM: Cancer vaccines. Nat Med 1998, 4(Suppl):525-531

7. Schroder S, Schwarz W, Rehpenning W, Loning T, Bocker W: Dendritic/ Langerhans cells, and prognosis in patients with papillary thyroid carcinomas: immunocytochemical study of 106 thyroid neoplasms correlated to follow-up data. Am J Clin Pathol 1988, 89:295-300

8. Sozzani S, Allavena P, Vecchi A, Mantovani A: The role of chemokines in the regulation of dendritic cell trafficking. J Leukocyte Biol 1999, 66:1-9
9. Rollins BJ: Chemokines. Blood 1997, 90:909-928

10. Mantovani A: The chemokine system: redundancy for robust outputs. Immunol Today 1999, 20:254-257

11. Filetti S, Rapoport B: Autoregulation by iodine of thyroid protein synthesis: influence of iodine on amino acid transport in cultured thyroid cells. Endocrinology 1984, 114:1379-1385

12. Scarpino S, Stoppacciaro A, Colarossi C, Cancellario F, Marzullo A, Marchesi M, Biffoni M, Prat M, Comoglio PM, Ruco LP: Hepatocyte growth factor (HGF) stimulates tumour invasiveness in papillary carcinoma of the thyroid. J Pathol 1999, 189:570-575

13. Naldini L, Vigna E, Bardelli A, Follenzi A, Galimi F, Comoglio PM: Biological activation of pro-HGF (hepatocyte growth factor) by urokinase is controlled by a stoichiometric reaction. J Biol Chem 1995, 270:603-611

14. Sozzani S, Sallusto F, Luini W, Zhou D, Piemonti L, Allavena P, Van Damme J, Valitutti S, Lanzavecchia A, Mantovani A: Migration of dendritic cells in response to formyl peptides, C5a and a distinct set of chemokines. J Immunol 1995, 155:3292-3295

15. Sozzani S, Allavena P, D’Amico G, Luini W, Bianchi G, Kataura M, Imai T, Yoshie O, Bonecchi R, Mantovani A: Cutting edge: differential regulation of chemokine receptors during dendritic cell maturation: a model for their trafficking properties. J Immunol 1998, 161:1083-1086

16. Prat M, Crepaldi T, Gandino L, Giordano S, Longati P, Comoglio PM: C-terminal truncated forms of Met, the hepatocyte growth factor receptor. Mol Cell Biol 1991, 11:5954-5962

17. Olivero M, Rizzo M, Madeddu R, Casadio C, Pennacchietti S, Nicotra MR, Prat M, Maggi G, Arena N, Natali PG, Comoglio PM, Di Renzo MF: Overexpression and activation of hepatocyte growth factor/scatter factor in human non-small-cell lung carcinomas. $\mathrm{Br} J$ Cancer 1996, 74:1862-1868

18. Weetman AP, Bennett GL, Wong WL: Thyroid follicular cells produce interleukin-8. J Clin Endocrinol Metab 1992, 75:328-330

19. Kasai K, Banba N, Motohashi S, Hattori Y, Manaka K, Shimoda SI: Expression of monocyte chemoattractant protein-1 mRNA and protein in cultured human thyrocytes. FEBS Lett 1996, 394:137-140

20. Ruco LP, Ranalli T, Marzullo A, Bianco P, Prat M, Comoglio PM, Baroni CD: Expression of Met protein in thyroid tumours. J Pathol 1996, 180:266-270

21. Zanetti A, Stoppacciaro A, Marzullo A, Ciabatta M, Fazioli F, Prat M, Comoglio PM, Baroni CD, Ruco LP: Expression of Met protein and urokinase-type plasminogen activator receptor (UPA-R) in papillary carcinoma of the thyroid. J Pathol 1998, 186:287-291

22. Stoker M, Gherardi E, Perryman M, Gray J: Scatter factor is a fibroblast-derived modulator of epithelial cell motility. Nature 1987, 327: 239-242

23. Trovato M, Villari D, Bartolone L, Spinella S, Simone A, Violi MA Trimarchi F, Batolo D, Benvenga S: Expression of the hepatocyte growth factor and c-met in normal thyroid, non-neoplastic, and neoplastic nodules. Thyroid 1998, 8:125-131

24. Mantovani A, Bottazzi B, Colotta F, Sozzani S, Ruco L: The origin and function of tumor-associated macrophages. Immunol Today 1992 , 13:265-270

25. Sallusto F, Lanzavecchia A, Mackay CR: Chemokines and chemokine receptors in T-cell priming and Th1/Th2-mediated responses. Immunol Today 1998, 19:568-574

26. Cella M, Sallusto F, Lanzavecchia A: Origin, maturation, and antigen presenting function of dendritic cells: Curr Opin Immunol 1997, 9:10-16

27. Dieu M-C, Vanbervliet B, Vicari A, Bridon J-M, Oldham E, Ait-Yahia S, Briere F, Zlotnik A, Labecque S, Caux C: Selective recruitment of immature and mature dendritic cells by distinct chemokines expressed in different anatomic sites. J Exp Med 1998, 188:373-386

28. Schofield JB, Alsanjari NA, Davis J, Maclennan KA: Eosinophilic granuloma of lymph nodes associated with metastatic papillary carcinoma of the thyroid. Histopathology 1992, 20:181-183

29. Thompson LD, Wenig BM, Adair CF, Smith BC, Heffess CS: Langerhans cell histiocytosis of the thyroid: a series of seven cases and a review of the literature. Mod Pathol 1996, 9:145-149

30. Safali M, McCutchen JM, Wright DH: Langerhans cell histiocytosis of lymph nodes draining a papillary carcinoma of the thyroid. Histopathology 1997, 30:599-603

31. Lindley R, Hoile R, Schofield J, Ashton-Key M: Langerhans cell histiocytosis associated with papillary carcinoma of the thyroid. Histopathology 1998, 32:180-189 